University of Nebraska - Lincoln

DigitalCommons@University of Nebraska - Lincoln

Faculty Publications -- Department of English

English, Department of

Summer 1983

\title{
Don Leon, Byron, and Homosexual Law Reform
}

Louis Crompton

University of Nebraska - Lincoln

Follow this and additional works at: https://digitalcommons.unl.edu/englishfacpubs

Part of the English Language and Literature Commons

Crompton, Louis, "Don Leon, Byron, and Homosexual Law Reform" (1983). Faculty Publications -Department of English. 58.

https://digitalcommons.unl.edu/englishfacpubs/58

This Article is brought to you for free and open access by the English, Department of at DigitalCommons@University of Nebraska - Lincoln. It has been accepted for inclusion in Faculty Publications -- Department of English by an authorized administrator of DigitalCommons@University of Nebraska - Lincoln. 


\title{
Don Leon, Byron, and Homosexual Law Reform
}

\author{
Louis Crompton, Ph.D.
}

The origin of the anonymous poem entitled Don Leon, written in the 1830 s but known to us only in an edition of 1866 , is one of the mysteries of English literary history. The title page describes the work as "A Poem by Lord Byron, Author of Childe Harold, Don Juan, \&c., \&c. and Forming Part of the Private Journal of His Lordship, Supposed to Have Been Entirely Destroyed by Thos. Moore," but it is less and more than this. Byron had died in 1824 and his memoirs were burned shortly after by a committee of friends and other interested parties.' The author and publisher of Don Leon were clearly trying to attract attention by pretending that the poem was part of the destroyed manuscript, but this claim was obviously not meant to be taken seriously. The numerous references in the text to parliamentary events of the thirties would have immediately informed any knowledgeable reader of that period that the poem had been written after Byron's death. By the sixties, these blatant anachronisms were less obvious; in fact, the man who republished it in 1866, William Dugdale, had at first believed the poem was genuinely Byron's.

The publication history of Don Leon is almost as obscure as its authorship, which has been keenly debated. ${ }^{2}$ We know that a version was in print before 1853 because in that year a correspondent signing himself "I. W." refers, in Notes and Queries, to "a poem (about 1500 lines) which professes to be written by Lord Byron, is addressed to Thomas Moore, and was printed abroad many years since." To identify the work, he quotes the opening line of Don Leon. ${ }^{3}$ But the earliest extant copies are from the 1866 edition of Dugdale, a publisher notorious chiefly for his pornographic titles. When, then, did the poem first appear? The extensive (more than ninety) notes on homosexual history and literature provide some hints, since many cite dated sources. Of these the greatest number (nine) draw on material published in 1833. Six of these are

Louis Crompton is Professor of English at the University of Nebraska, Lincoln. His study Shaw the Dramatist received the Phi Beta Kappa Christian Gauss award for 1969. He has published "Gay Genocide: From Leviticus to Hitler" in The Gay Academic, ed. Louie Crew, and "Homosexuals and the Death Penalty in Colonial America" and "The Myth of Lesbian Impunity: Capital Laws from 1270 to 1791" in the Journal of Homosexuality. 
references to an important book, A Free Examination, which we shall discuss later, but one of the others cites no fewer than six newspaper articles on arrests for homosexual offenses in that year. ${ }^{4}$ Given the ephemeral interest of these items it is likely that the notes were first written up in 1833. This suggests that some version of the poem existed at that time. It is implied that the annotator is a person different from the poet; occasionally he corrects him. Notes 31,66 , and 67 give magazine or newspaper reports belonging to 1836 . The poem may have been emended or enlarged then, as the text contains one reference to an event in 1836 . Perhaps the first edition appeared at that time. An even likelier year is 1842, since note 27 speaks of "its being now 1842," which would hardly make sense unless immediate publication were envisioned. ${ }^{5}$

The poem is an impressive effort, running to more than fifty pages; the notes are almost as long again. Written with great verve and energy, its expression is concentrated and its ideas carefully organized. Though it is not the literary masterpiece it has been called, it is a work of real literary significance. It has generally been described as a satire in the tradition of Byron's English Bards and Scotch Reviewers, The Curse of Minerva, etc., but its rhymed pentameters surpass Byron's polemics in substance, force, and interest. Obviously, the author had given many years of thought to his subject. Though Don Leon purports to be an account of the homosexual side of Byron's life and provides much accurate information about his pederastic love affairs with Robert Rushton, John Edlestone, and Nicolo Giraud, this is not, eventually, where the center of interest lies. The poem is in fact a rhymed pamphlet in favor of homosexual law reform that incorporates a pseudoautobiography and erotic jeux d'esprit. Granted that satire has always been a loose and accommodating form, these diverse strands of Don Leon make it unique in English literature.

But why should an unknown poet have produced such a document in or about 1833? The answer lies in the plight of England's homosexual minority, who at that time faced the threat of hanging. On the Continent, Russia, Austria, Prussia, and Tuscany had all, late in the eighteenth century, adopted reform codes that dropped the death penalty for sodomy; France had decriminalized adult homosexual relations entirely in $1791 .^{6}$ In England a campaign to mitigate the rigors of a very severe criminal code began in 1808 under the leadership of Sir Samuel Romilly. ${ }^{7}$ However, no real advance was made in reducing the large number of capital offenses (over two hundred) until Parliament appointed a Committee of Inquiry into the State of Criminal Law in 1819. The debate that led to the appointment of the committee showed a significant contrast in liberal and conservative positions on homosexuality and the law. Lord Castlereagh, who opposed setting up the committee, divided crimes into two classes: those indicating "deep moral depravity or national degrada- 
tion," such as murder, rape, and "assaults with the attempt to commit unnatural offenses"; and lesser crimes, such as those against property. ${ }^{8}$ (Here it is worth noting that "assaults" meant, not actual acts of sodomy, which were then capital, but often merely cases of what we would now call solicitation, which at the time were punished by fines and imprisonment. That Castlereagh should have ranked these with murder was typical of English hysteria on the subject.) The more liberal Sir James Mackintosh drew the line differently. He made three classifications: first, the worst crimes, murder and acts likely to cause death; second, arson, armed robbery, piracy, and "other offenses . . . which it would be painful to specify"; and finally, larceny and fraud. ${ }^{9}$ Disappointingly, the report of the committee of 1819 made many recommendations but left untouched the question of sexual crimes. Some progress was made under Sir Robert Peel, who as home secretary in Wellington's cabinet in the twenties succeeded in reducing the large number of capital crimes against property. After the Reform Bill of 1832, the chances of abolition were enhanced when Lord John Russell replaced Peel at the Home Office and appointed a new panel of commissioners with Benthamite views in 1833.

The question foremost in the mind of the Leon poet was whether the new commissioners would recommend removal of the death penalty for homosexuality. The law was anything but a dead letter. In 1819-25 some fifteen men were hanged, in 1826-30, seven; there was one hanging in 1831, two in 1833, four in 1834 , and two in 1835 - a total of about eighty since the beginning of the century if we include a score of naval hangings (the last of which took place in 1829). ${ }^{10}$ If Parliament ranked even an attempted homosexual act as a "crime of national degradation," there was little hope; if Parliament followed Mackintosh and distinguished it as a crime of lesser import, there was a chance for abolition. The prognosis did not look good. There was, for one thing, the ominous continuation of executions; moreover, in 1828 Peel had actually sponsored a bill that made conviction in sodomy cases easier. In the eighteenth century it had been necessary to prove both penetration and emission to convict; now it was proposed to make proof of penetration alone sufficient. The debate on the 1828 measure makes curious reading. Peel referred to homosexuality only as the crime "inter Christianos non nominandum" and recommended reducing the "two kinds of proofs" to "one," without giving any more specific indication as to what he was talking about." Such was the reticence of the day.

With the passage of the Reform Bill in 1832 and the election of a more liberal parliament the next year, most oppressed groups in England hoped for some relief from traditional abuses. Nonconformists had been relieved of disabilities by repeal of the Test Act in 1828, Catholic Emancipation had come in 1829 , and it was expected that the reformed 
House of 1833 would crown decades of agitation by ending black slavery (which it did). But the year turned out to be a bad one for homosexuals, and the Leon poet's rhetoric is mixed with more rage and despair than hopeful expectations. The poem opens with a strong protest against hangings and police entrapment:

Thou ermined judge, pull off that sable cap!

What! Can'st thou lie, and take thy morning nap?

Peep thro' the casement; see the gallows there:

Thy work hangs on it; could not mercy spare?

What had he done? Ask crippled Talleyrand,

Ask Beckford, Courtenay, all the motley band

Of priest and laymen, who have shared his guilt

(If guilt it be) then slumber if thou wilt;

What bonds had he of social safety broke?

Found'st thou the dagger hid beneath his cloak?

He stopped no lonely traveller on the road;

He burst no lock, he plundered no abode;

He never wronged the orphan of his own;

He stifled not the ravish'd maiden's groan.

His secret haunts were hid from every soul,

Till thou did'st send thy myrmidons to prowl. . . . (1-16)

The "sable cap" is, of course, the black cap English judges put on when they were about to pronounce sentence of death. The particular hanging that seems to have aroused the poet is that of Captain Henry Nicholas Nicholls on 12 August 1833. The Times had published details of his trial a week earlier; when it reported the hanging, it mentioned a companion of Nicholls, similarly charged, who had committed suicide. ${ }^{12}$ The annotator of Don Leon preserves only the thinnest pretense that Byron had written these lines: "In reading the opening of this poem, it would almost seem that the author of it had in his eye Mr. Justice Park [who pronounced sentence on Nicholls] were it not that the supposed date of the poem would imply an anachronism" (note 1). The poet goes on to remind us that capital laws against housebreaking and robbery without violence have been repealed and asks, by implication, whether consensual sodomy seems as threatening. He is also outraged at the use of plainclothesmen who insinuate themselves at homosexual rendezvous and invite solicitations.

Despite the differences of style and rhetoric, the concerns of the Leon poet inevitably suggest comparison with Bentham's arguments for reform in his manuscript notes and essays of 1774, 1785, and 1814-16. ${ }^{13}$ The topicality of the poem and its preoccupation with parliamentary matters link it with another contemporary publication of mysterious provenance. 
This is the legal study already noted, A Free Examination into the Penal Statutes, xxv Henr. VIII, cap. 6, and v Eliz. c. 17, i.e., England's historical sodomy laws. The book is ascribed to "A. Pilgrim \&c. \&c.," presumably a pseudonym. Henry Ashbee in his Index Librorum Prohibitorum describes a copy bearing the date "London, 1833," though he suggests that it was "printed probably in Paris." He also gives a fuller version of the title, which indicates that it was "addrest to Both Houses of Parliament." ${ }^{14}$ Presumably this was a kind of legislator's brief on the subject of homosexual law reform. It must have been a work of some substance if the reference to "page 771" in note 30 to Don Leon is not a misprint. Note 24 tells us that "it is become very scarce," which suggests that it was not widely distributed. No copy has been described in the twentieth century. Since it appears to have been the first book on homosexuality ever published in English, the loss to gay scholarship is very considerable. We can derive some idea of its scope and tone from the quotations in the Leon notes and in Ashbee. First, Pilgrim's estimate of Europe's homosexual population, radical for its age, seems closer to the statistics of Kinsey than to the conservative guesses of Bentham. Though the laws in England are most often enforced against the poor, he conjectures "that the taste has been in all ages that of the most distinguished individuals, and that we might count perhaps as many delinquents in the great continental cities now, as there were in Athens, or in ancient Rome." 15 On the historical side, he notices Aristotle's statement that homosexuality was encouraged among the Cretans for Malthusian ends and gives a summary of Roman law and a description of Roman manners (notes 76 and 24). Pilgrim laments the reiteration of such names as Tiberius, Nero, Caligula, and Heliogabalus in homophobic polemics and protests the prejudicial omission of any reference to the legion of "the virtuous, the brave, the generous and the temperate" who shared the same orientation (note 24). A Free Examination also draws the inevitable comparison between French tolerance and English harshness and decries the credulity that in England led men to follow uncritically religious laws that decide "our very destiny and existence" (note 8).

If "A. Pilgrim" is a murky and unknown figure, the identity of the Leon poet is also veiled in mystery. G. Wilson Knight, who in 1954 first rescued the poem from disreputable obscurity, has suggested that it is by a playwright-poet Byron knew and caroused with, George Colman, the younger. ${ }^{16}$ Byron, who came to know Colman through their work at Drury Lane Theatre, celebrates this wit and conviviality in his journals. The parallels in vocabulary and moral attitudes between Don Leon and some of Colman's own satires are striking, but ascriptions of authorship based on stylistic similarities are always tenuous. There is also the question of Colman's age and ill health - he died in 1836 at 73 . Doris 
Langley Moore has argued against Colman's authorship on these and other grounds and has hinted at another candidate. ${ }^{17}$

Indeed, all we can say with certainty about the Leon poet is that he had a clever (and sometimes highly erotic) wit, a talent for writing forceful couplets, and as we shall see, a remarkable knowledge both of Byron's pederastic interests and of parliamentary debates and personalities in the years 1824-33. The poem itself is full of ideas and information, though when it speaks of Byron one cannot always tell how much is factual and how much imagined. Since the kaleidoscopic turns of thoughts are so many that even someone who has read it two or three times may have only a confused recollection of its structure and logic, a fairly extended summary may be valuable. It will also communicate, as no other approach can, the concentrated energy of the poem. Because the Leon poet purports to be speaking in the person of Byron, I shall refer to him as Byron in this résumé. Note, however, that the pseudo-Byronic mask is often casually dropped in the argumentative sections.

After the opening protest (quoted above), Byron begs Moore to give a sympathetic ear to his "swelling rage" and to print his thoughts unaltered. (This is almost the only reference in the text to the pretense that the poem has some connection with the famous memoir.) England, he complains, tolerates the most open forms of prostitution but condemns "poor misogynists" to the gallows and vilifies them incessantly in the press. The Sodom story is urged against them, though many other ancient cities have vanished without anyone's interpreting their disappearance as instances of divine displeasure. The venial clergy approve only those unions that bring them marriage or baptismal fees, and are blind to a love that will "Produce no other blossoms than its own" (126).

Even during his teens, Byron tells us, he was aware of an instinct that drew him to other boys. Social custom allowed him to express his love for such young women as Mary Chaworth and Margaret Parker, but not these other longings. Now, looking back, he realizes that his feelings for boys like his page Robert Rushton, which once passed for lordly patronage, had a sexual element:

Full well I knew, though decency forbad

The same caresses to a rustic lad;

Love, love it was, that made my eyes delight

To have his person ever in my sight. (169-72)

At Cambridge, he feels alienated from the common revels and longs for a kindred soul, who might return his affection. He hears John Edlestone singing in the choir, and friendship ripens into love:

Oh! 'tis hard to trace

The line where love usurps tame friendship's place. 
Friendship's the chrysalis, which seems to die,

But throws its coils to give love wings to fly. (219-22)

He is tormented by the intensity of his emotions and struggles to understand them. Moral law opposes his desires, but to him they seem natural, since they spring from his inner being. He begins to question traditional standards - after all, he is not about to ruin a virgin, betray a husband, or beget a bastard. He seeks to divert himself from these anxieties by losing himself in the pleasures of classical poetry but is inadvertently driven back to the question. Horace, he discovers, loved youths, Virgil sighed for Alexis, Socrates and Plato spoke openly of kissing ephebes, and Plutarch praised the love of Epaminandos for Cephidorus. He rejects these loves as pagan perversions, but when he turns to the history of Christianity, he discovers such attachments again in the lives of popes, devotees, kings, scholars, jurists, and poets -

Nay, e'en our bard, Dame Nature's darling child,

Felt the strange impulse, and his hours beguiled

In penning sonnets to a stripling's praise,

Such as would damn a poet now-a-days. (315-18)

Obviously, "the great, the wise, the pious, and the good" have had the same susceptibility. In alarm he rejects books and history as morally dangerous guides. But untutored schoolboys take the same path even if they are "in Justine unread." This may be better, however, than their risking disease through harlotry. School authorities should quietly ignore such "illicit play": only fools would make a public issue of it.

Edlestone dies (the poem is inaccurate in making this occur before Byron left England for Greece in 1809), and weary of Cambridge, Byron seeks the freedom of the East:

Love, love, clandestine love, was still my dream.

Methought there must be yet some people found,

Where Cupid's wings were free, his hands unbound

Where law had no erotic statutes framed,

Nor gibbets stood to fright the unreclaimed. (423-27)

(We now know, of course, that Byron did indeed have such thoughts in mind when he sailed for the East. ${ }^{18}$ ) The account of Byron in Greece is particularly full and striking. In Constantinople he is excited by the traditional tourist visit to taverns with dancing boys but hides his feelings from his friend Hobhouse, affecting to be horrified. He feels alienated from his countrymen and is relieved when he parts from Hobhouse at Zea. Byron warmly praises the latter's political work for radical causes in England but himself follows other pursuits: "A demon urged, and 
with Satanic force / Still goaded on" (494-95). He is enraptured by the historical associations of Athens, swims at Piraeus, moves to a monastery, and then takes up residence in the nearby Lantern of Demosthenes. ${ }^{19}$

While searching through the ruins of the city he is invited home by a citizen. There the man's son attends the guest in Oriental fashion. Byron is struck by the boy's beauty, courts him, and is urged by the father to take him as his page. He tries to cultivate the boy's mind, gazes on him with affectionate lust while he sleeps, and cares for him with tender solicitude. The dual fires of poetic inspiration and carnal desire rage in him. Though he has met the Macri sisters, they inspire him only poetically; his real passion is for this boy (Nicolo Giraud, who is named in line 678), who finally gratifies him in the convent cell: "So boldly I set calumny at naught,/ And fearless utter what I fearless wrought" (690-91). (Letters have come to light in the present century to confirm this detail. ${ }^{20}$ ) There follows a description of how the then Waiwode (or mayor) of Athens was attended by a beautiful catamite on public occasions; such openness is common at every level of Turkish society.

The Leon poet, now dropping any effort to relate his plea to the experiences of the historical Byron, at this point embarks on a frank apology for homosexuality. First, Malthus has dramatically shown the danger of overpopulation, which must breed starvation if not controlled. One must take into consideration the great diversity of sexual tastes. Some men (like the English ambassador to Constantinople) are born exhibitionists. Others seek cunnilingus, flagellation, or fellation from women. Incest and lesbianism are not uncommon. Some women have died to preserve their virginity, but others, like the Countess of Blessington, have risen to wealth and social prominence by judiciously losing theirs. When bench and pulpit reiterate endlessly the view that the sexual behavior of the English is morally superior to other nations, they are hypocritical, and never more so than when, in the case of homosexuality, they give the impression

That self-condemned, decried, ineffable, Innominate, this blackest sin of hell, Had fled dismayed to some Transalpine shore

To sully Albion's pudic cliffs no more. (854-57)

The press exposes arrested men with cruel glee and titillates its readers with scabrous police reports. The rich and secure feign horror, never taking into account what may have led a man into these paths: perhaps he was corrupted when young; perhaps he shrank from the idea of seducing a woman; perhaps he was ugly or shy, or averse to the ribaldry or diseases of harlots. 
Every rank of English society is involved. The average British soldier or tar is a priapist prone to take his pleasure where he finds it. Teachers relish flogging half-naked schoolboys. Parliament itself is not immune. Looking into the future, Byron prophesies that a member famed for his learning and book collecting will be forced to flee the country and later will be cruelly maligned in a libel suit brought by a father against an editor for having linked his son's name to the exile's. Another, a young officer who fought in Sicily, will be tragically drawn into the case. A third member, a pious advocate of prison reform and Negro rights, will also face the bitterness of exile. The poet complains indignantly that Peel's revisions of the law have worsened matters. Liberal legislators like Richard Martin, who led the movement to protect animals from cruelty, and legal reformers like Sir James Mackintosh remain callously indifferent to the plight of homosexuals.

Near the Speaker's chair where Charles Manners-Sutton presides and waits for his peerage, sits Sir Stephen Lushington, whom Byron curses for having turned Lady Byron against him. He recalls some of his happy moments with his wife; in a bedroom colloquy he describes Moslem manners to her and pictures the life of harem women and the Turks' passion for boys. Annabella expresses curiosity, and Byron enlightens her about Anacreon, Virgil, and Catullus. She is somewhat shocked but allows him to practice anal relations (which he extols) with her, because her pregnancy makes ordinary relations awkward. Later, when they are estranged, Annabella is pressed to reveal this secret, and friends use it to separate her from her husband.

After a second appeal by Byron to Thomas Moore to tell the truth and not bowdlerize his life, if Moore should ever write it, the poem abruptly flashes back to Parliament to cast a spotlight upon another figure, a friend (William Bankes) whom Byron had known since his college days. Despite his wealth, the fame of his travels, and his high social standing, Bankes will eventually suffer Byron's fate. Bankes's friend Peel, when he passes Bankes's darkened house and remembers what a staunch supporter he has been in Parliament, may then regret his failure to reform the law.

In conclusion, Byron bitterly recalls what abuse he suffered as a man after being praised so highly as a poet. But England is not the universe: her prejudices cannot stand before the light of reason. God's law is higher than Parliament's; it is as outrageous to persecute sexual as religious heresy. Then with a final impish gesture the poet ends with a series of crude and exuberant epigrams on the pleasures of anal intercourse.

Don Leon is remarkable for the challenge it posed to contemporary prejudices against homosexuality, and for the new facts it purported to give about Byron's life. Who the source of these facts was we do not 
know. Possibly, like Colman, the poet was a confidant of Byron's. Friends of Byron's may have enlightened him, or he may have met someone who either knew Byron in Greece or picked up gossip there. Thomas Moore, whose Life of Byron appeared in 1830, had described Byron's attachments to Rushton, Edlestone, and Giraud but was careful to represent them as romantic friendships and nothing more. We now know from many sources that these affairs had a sexual element. G. Wilson Knight speculated extensively on this possibility in 1957 in Lord Byron's Marriage. The thorough researches of Leslie Marchand and Doris Langley Moore have provided conclusive documentary evidence in the form of Byron's letters from Greece to Hobhouse, Hobhouse's marginalia to Moore's Life, Lady Byron's memoranda, etc. ${ }^{21}$

There are, however, material facts the Leon poet was not aware of. He did not realize, for example, that the "Thyrza" lyrics were elegies on the death of Edlestone; and he had no inkling of Byron's love, during the final months of his life, for the fifteen-year-old Loukas Chalandrutsanos. But he goes far beyond Moore in providing details about Byron's first stay in Greece. Moore does not mention the visit to Galata or (of course) the consummation in the monastery. We have confirmation of the first from Hobhouse's journals and of the second from Byron's "Greek epistles," as he called them. It appears that the Leon poet had some informant who knew the Athenian scene: in note 40 the story of the Waiwode is ascribed to Lord Plymouth. But he is not always accurate here: he errs, for instance, in representing Nicolo Giraud as living with his father rather than with his brother-in-law.

Whatever its source, the story is worked out with much sensitive detail. The gradations by which ardent friendship melts into erotic awareness are depicted with some subtlety. It is difficult to think of any comparable description of the awakening of homosexual feeling in English literature before the twentieth century. As a portrait of an adolescent struggling toward self-awareness Don Leon compares with Forster's Maurice, which was not written till eighty years later. But where Forster in his novel gives us the psychosexual development of two young men who are, respectively, a classical scholar and a conventionally minded businessman, Don Leon shows us the awakening of a sensual poet.

The sympathetic dramatization of the stages by which Byron realized his feelings for the male sex works in two ways - as a biographical revelation, and as a rhetorical device to moderate homophobic sentiment by showing the anguish of a sensitive boy. The "argument from antiquity" is cleverly handled by having Byron discover the truth about Greek and Roman society in his reading. The "great men" argument is less adroitly managed; the catalogue is set forth effectively, but hardly as a boy's discoveries. The lines on Shakespeare bear some relation to a 
comment on the sonnets made by Byron and recorded by George Finlay during the poet's last days in Greece. ${ }^{22}$

As for the sociological arguments for tolerance, it is interesting to compare these to Bentham's. There is the same citing of Malthus (who did indeed list "unnatural acts" as a check to population: "Economists, who seek the world to thin,/ 'Tis you who teach this so named deadly sin" (775-76). Both protest strongly against the sensationalism and virulence of the British press. Bentham had complained in his notes of 1816 that

A battery of grape shot composed of all the expressions of abhorrence that language has given or can give birth to is by each newspaper and every other periodical kept continually playing upon this ground. No wonder that down to this instant no man with the torch of reason in his hand should have found nerve enough to set foot on it. Miscreant! You are one of them then! Such are the thanks he would receive, such the bad thanks which any man who should attempt to carry upon this part of the field of morality those lights to which all other parts are open ever could or even now can rationally expect to receive. ${ }^{23}$

Like Bentham, the Leon poet also argues that homosexuality is less of a social evil than extramarital pregnancies and adultery and is thus less dangerous than illicit heterosexual relations. Bentham, in a prospectus to a proposed book on homosexuality addressed to William Beckford, painstakingly enumerated every kind of sexual conduct, heterosexual and homosexual, he could think of in order that prejudice might be "perplexed and weakened" by their sheer numbers. ${ }^{24}$ The Leon poet does something similar, dwelling on a variety of heterosexual techniques, some of which border on the bizarre. This is perhaps the least acceptable part of the poem: there is something offensive in his lubricious bandying of names and initials. Where Bentham presents his list in a scientific spirit with dry logic, the Leon poet writes with a smirk that is rather reminiscent of Martial; his approach is too much like blackening the kettle to brighten the pot.

Another detail likely to puzzle the modern reader is the use, in this passionately antihomophobic poem, of virulently homophobic language. This diction is hard to explain. In other contexts such language might be explicable on rhetorical grounds. A debater in the public arena in that age, given the force of popular sentiment, might have adopted abusive language to allay suspicions about his own tastes. Or he might have felt that arguments for less-harsh legal punishment came with more effect from someone who expressed moral horror at homosexual behavior. So 
strong was the taboo on discussion that many nineteenth-century writers, even in a scholarly legal or historical context, seem to have felt that homophobic abuse was a necessary coin to be paid for the privilege of touching even briefly on a forbidden topic. So Bentham felt compelled to use pejorative language (totally at odds with his feelings) in his manuscript essay of 1785 , and so, too, Byron in the famous lines on Beckford he had at first intended for Childe Harold. ${ }^{25}$ But these considerations would hardly seem to hold in the case of the anonymous Leon poet, who frankly celebrates the joys of same-sex intercourse. To find this enthusiasm coupled with references to homosexuality as a "morbid lust," "sport obscene," "rank disease," "impure delinquency," etc., is puzzling. G. Wilson Knight explains the anomaly as an attempt at "balance," but the effect is more like a linguistic, if not moral, schizophrenia.

It is also difficult, since the chief aim of the poet is to change the reader's mind about capital punishment, to account for the explicit eroticism of some of the later pages. Though it is a minor element, there is enough in this vein to have tempted most nineteenth-century readers to dismiss the production as a mere essay in pornography, as the Victorians understood the term. This must have drastically limited its circulation and weakened its impact on all but the least prudish. One possibility is that the more glaring passages - the bedroom scene and the final peroration - were not added until 1842, by which time all hopes for homosexual law reform, as we shall see, had been finally laid to rest. Perhaps the author felt that, given the circumstances, the only channels of distribution open to him were under-the-counter sales in shops dealing in erotica. This may have prompted him to add these passages. Ironically, spicy details, which, under Victorian law, would themselves have justified the pamphlet's destruction by the authorities, in fact preserved it, since the erotic sections seem to have been what motivated Dugdale to print his version.

Some of the contrasts with Bentham, both in tone and argument, result from the change that took place in the political situation between the Regency (when Bentham did most of his writing) and the 1830s. In 1818 , when Bentham finished his most extensive notes in favor of the decriminalization of sodomy, criminal law reform in England was still in the future. By 1833, the death penalty had been abolished for scores of offenses. This movement in the Commons and the Lords had aroused, for homosexuals, both hope and despair. The poem is consequently full of minutiae relating to Parliament and parliamentarians. Though these create many obscurities for the modern reader, they also give the poem substance and reality. Don Leon contains detailed accounts of four members who found themselves embroiled with or threatened by the law in homosexual scandals, and a fifth is mentioned in the notes. The men 
whose fates the poet and annotator limn at some length were Richard Heber, James Stanhope, Henry Grey Bennett, Baring Wall, and William Bankes.

Richard Heber, the bibliophile, was a friend of John Cam Hobhouse. Via Hobhouse, Byron sent his compliments from Ravenna to Heber upon his election as member from Oxford in $1821 .{ }^{26}$ When Heber died in exile in 1833, the English press was full of lengthy obituaries, most of which ignored or made only veiled references to his ostracism. Walter Scott had praised him as "Heber the magnificent" for his library, rendered him thanks in the notes to the Waverley Novels, and celebrated their friendship in the sixth canto of Marmion ${ }^{27}$ Heber's collection of early English books was regarded in his day as the most impressive ever assembled; he left eight houses full of volumes in England and on the Continent. The details of his case are obscure. Scott noted that "his life was compromised but for the exertions of Hobhouse under Secy of State who detected a warrant passing through the office. ${ }^{28}$ Forewarned, Heber fled to Brussels. Next year, rather than face the publicity of an election, he resigned his seat. Scott, who had wondered at his disappearance, confided in his journal for 25 June 1826 that a friend had

mentioned to me last night a horrid circumstance about a very particularly dear friend who lately retired suddenly and seemingly causelessly from parliament. He ascribed [it] to his having been detected in unnatural practices - I hope there may be doubts of this though he spoke very positively and the sudden and silent retreat from a long wishd for seat look[s] too like truth. God, God whom shall we trust!! Here is learning, wit, gaiety of temper, high station in society and compleat reception every where all at once debased and lost by such degrading bestiality. Our passions are wild beasts. God grant us power to muzzle them. ${ }^{29}$

Scott, who shared the common British prejudices of the day, seems not to have reflected that it was an arbitrary social taboo that had driven Heber from England.

Some dim and indirect light on the circumstances of Heber's flight glimmered in the press. On May 14, John Bull published a typical clever-vicious notice: "We understand that Mr. Heber's complaint (for which he has been recommended to travel upon the Continent) is an overattachment to Hartshorn." ${ }^{30}$ The Leon poet puns on the name of the aromatic (sal volatile) in his verse, and note 63 tells us that "Mr. Heber's shame was brought to light in consequence of an action for libel, instituted by Mr. Hartshorn against the editor of a newspaper, wherein pointed allusions were made to a supposed intimacy between Mr. Heber and Mr. Hartshorn's son." In a very detailed account of his scholarship 
and politics, published on the occasion of Heber's death, the Annual Register reported: "In the year, 1831 he returned to England, but not into the society which he had left; for rumors had been in circulation degrading to his moral character. With the exception of his visits to the auctionrooms and booksellers' shops, he lived entirely secluded among his books at Pimlico or Hodnet. ${ }^{31}$ Scott never attempted to communicate with him.

The identity of the next parliamentary portrait in Don Leon is less clear. Note 65 speculates that the "youth with courtly manners" who had fought in Sicily was "probably the Honourable James Stanhope," the younger brother of Leicester Stanhope, Byron's colleague in the Greek wars. He is described as "the intimate friend of Mr. Heber, [who] soon after the disclosures made concerning the latter gentleman, hung himself in an outhouse in Caen Wood." The Times for 8 March 1825 contains a long article on Stanhope's suicide but does not hint at its cause. Since the date is earlier than Heber's flight, it is possible that the identification is wrong.

The antislavery crusader whom the Leon poet chided for his failure to take up homosexual law reform was Henry Grey Bennett, member for Shrewsbury and a friend of Hobhouse. An active debater, Bennett suddenly disappears from the pages of Hansard in the mid twenties. The parliamentary sketches in Don Leon are all introduced, rather awkwardly, as prophecies by the omniscient Byron; one ends with a couplet: "An exile to a foreign land he'll fly, / Neglected live, and broken-hearted die" (986-87). Since Bennett did not die till June 1836, these lines have caused a debate about the date of their composition. Knight has suggested that here we have a genuine anticipation by the Leon poet of Bennett's demise, rather than a post facto one. Doris Langley Moore has objected to this as unlikely. However, a date of 1836 for the poem as a whole seems to me too late.

At the end of this lengthy section on Parliament Byron is made to spy Charles Manners-Sutton in the Speaker's chair. Sutton is decried as a timeserver who "Counts Ayes and Noes to make himself a peer" (1040). It has been assumed that these lines were written after March 1835, when Sutton was elevated to the Lords. But Sutton's obvious desire for a peerage had been a political issue as early as 1833 . At the opening of the reformed Parliament, it had been expected that Sutton would retire as Speaker of the House. But when his hoped-for peerage was not forthcoming, Sutton stayed in the post, a move that gave some offense, since he had opposed the Reform Bill. ${ }^{32}$ The jibe might thus have been penned any time after January 1833; probably soon after, as it is hard to imagine so ephemeral a matter would have engaged the poet's attention after the controversy had died down.

Another homosexual episode involving a member of Parliament is mentioned only in the notes. In February 1833, Baring Wall, the member 
for Guilford, was accused by a policeman, whose testimony was explicit and detailed, of making sexual advances late at night in Harley Street. ${ }^{33}$ Wall was tried for the crime of "attempting to commit an unnatural offense," but the jury refused to believe his accuser and Wall served in the House till 1852. However, the year 1833 seems to have been a bad one for legislators in relation to such accusations, for in June another respected member of long standing faced a similar charge. This was William Bankes, who for many years had been on close terms with Byron. When he was at Cambridge, Byron called Bankes his "collegiate pastor, and master, and patron" and often joined Bankes and Charles Skinner Matthews, another homosexual friend, in Bankes's rooms. ${ }^{34}$

During his first year at Trinity College, Byron identified Bankes and Edward Long as his closest intimates. In 1807, when Byron was about to publish his juvenile poems, he submitted them to Bankes's judgment and took his harsh criticism in good part. ${ }^{35}$ Five years later their paths crossed again under ironic circumstances: Bankes proposed to Annabella Milbanke shortly after Byron had made his first proposal, and like him was turned down. He then went on an eastern journey that lasted some eight years. Byron wrote recommendations when his friend proposed to visit Albania and, impressed by Bankes's scholarly discoveries, took a vicarious pride in his "perilous researches." 36 "Bankes is a wonderful fellow," Byron wrote to his publisher John Murray in 1820, "there is hardly one of my School and College Contemporaries that has not turned out more or less celebrated"; "I love and esteem him." Byron, who generally avoided English visitors during his exile in Italy, wrote a warm invitation to Bankes to join him in Ravenna to celebrate the carnival of 1820 . When Bankes returned to England, his country house in Dorset became a showplace for antiquities, including a famous obelisk, and was often visited by the Duke of Wellington, who was a close personal friend. ${ }^{38}$ From 1822 to 1826 Bankes sat in Parliament as the member for Cambridge; later he was elected as the representative from Marlborough and then from Dorset.

On 7 June 1833, he was arrested and accused of sexual misconduct with a guardsman in a public convenience near the House of Commons. According to the Times, the police station where Bankes and the soldier were held overnight was surrounded by an angry crowd early in the morning. "Long before the hour of commencing business, at least 2,000 persons had assembled," and when the soldier was brought up the police escort "had the greatest difficulty in keeping the mob off. The yells and execrations of the crowd were tremendous." ${ }^{39}$ Such hostile mobs of thousands were commonplace in London when news of arrests on homosexual charges circulated; seventeen years earlier between thirty and fifty thousand had been drawn to the pillorying of the Vere Street coterie.

The crowd objected loudly to being excluded from Bankes's hearing 
and shouted, "It's because he's a rich man!" The magistrate, intimidated by the multitude, or recollecting the flight of the Bishop of Clogher and the uproar it had occasioned a decade earlier, set bail at the immense sum of $£ 12,000$ (about $\$ 300,000$ in today's currency). When the soldier left the court, a sergeant of his regiment, the Coldstream Guards, seized the cap from his head and tore off the lace.

The trial was postponed till December, perhaps in the hope that feeling would subside. Wellington, who had witnessed the Clogher affair at close hand, must have felt alarmed. Given British traditions, Bankes's conviction might have led to the hanging of a Tory member of Parliament at a moment when radical sentiment still ran high. The strategy adopted was the one that had succeeded in the case of Wall - to overawe the jury with character witnesses. Wellington himself testified. So did Samuel Rogers, Dr. Butler (the headmaster of Harrow), and the high bailiff of Westminster; the earls of Callaghan, Liverpool, and Brecknock; Lords Burglesh, Cage, Cowley, and Stuart; and a number of members of Parliament. The jury, duly impressed, found the men not guilty and "without the least stain on their character." Eight years later, when Bankes was again arrested for a similar offense, he followed in Byron's footsteps by retiring to Venice, where he died in 1855.

Don Leon was written to forward the cause of homosexual law reform, but the movement (if it can be called that) did not prosper. The Commission on Criminal Law appointed in 1833 issued their report on 20 June 1836. They recommended reducing capital offenses to eight crimes, all of which (except sodomy) involved violence or danger to life. Though they tabulated the statutes of ten American states, none of which made sodomy capital for the first offense, their one reference to homosexuality was a single sentence: "A nameless crime of great enormity we, at present, exclude from consideration." ${ }^{41}$ A bill to abolish the death penalty for rape and sodomy passed the Commons in 1841 (where the debate touched only on rape), but sodomy law reform was killed in the Lords. On 17 June, the Earl of Wicklow argued that if the Lords passed such a law, "they would lower themselves in public opinion; for as the organ of the public voice, they would sanction what the people of this country would never confirm - that sodomy and rape were not crimes of so heinous a character as to deserve death." Next day, the Earl of Winchelsea proposed an amendment to retain capital punishment for homosexuality alone. "Their Lordships, he was convinced, would do great violence to the moral feelings of a very large class of the community, if they exempted this crime from the penalty of death." ${ }^{42}$ As a result, though executions ceased in 1835 , over two hundred homosexuals were sentenced to hang in the next twenty years. In some years the number of such sentences exceeded those for murder. In 1861, a comprehensive measure consolidating and revising portions of the English criminal law 
was passed, and the death penalty for sodomy was reduced to life imprisonment, a sanction that remained unchanged for more than a century.

Though it is impossible to speak with real certainty of the author and the date of Don Leon, certain considerations do suggest themselves. First, it seems altogether likely that, whatever touches were added later, the poem was completed substantially in its present form sometime in the late summer or early fall of 1833 . The two cases that seem to have provoked the work were the arrest of William Bankes in June and the execution of Nicholls in August. The Bankes episode may have suggested to the poet that members of Parliament would now be ready to listen to reform arguments, since a distinguished member of the lower house had become a victim of the law. The earlier case of Baring Wall was omitted from the poem, since, though he had faced an ordeal in many ways parallel to Bankes's, he had been acquitted. Because Bankes's own acquittal in December made his case moot as well, it is likely that the section of the poem devoted to Bankes (which is very near the conclusion) was finished before his trial took place. There is also the curious fact that the list of arrests for 1833, in note 56, includes cases that occurred in February, April, May, June, and early August, but none later. Probably, then, the note was compiled in late August or shortly afterwards.

As for the author, one is struck by his minute knowledge of details pertaining to the Commons. He notes, for instance, that Stephen Lushington sat near the Speaker, and that the "youth with courtly manners" (who may or may not have been Stanhope) shared the same row with the "elder Bankes," i.e., Bankes's father. No one who had not frequented the House often and been closely familiar with its membership would have been aware that these two obscure parliamentarians sat in the same row, or could have told the reader that James Brogden spoke in a shy manner at certain moments (as in line 1020). If the author was not an elected representative he was certainly someone whose duties or interests brought him into close relation with Parliament. Given his passionate commitment to homosexual law reform, it seems likely that he had some contact with the coterie of reformers who compiled A Free Examination in 1833. His intimate knowledge of Byron's life also suggests that if he had not known Byron, he was at least a confidant of some friend of his. Possibly this friend was William Bankes himself, who, on visiting Byron in Italy on the way home from his eastern travels in 1821, may have exchanged confidences with him.

But whoever he was, the Leon poet has left us a unique document. No further candid discussion of Byron's homosexuality appeared in English until 1935, when Peter Quennell published his Byron: The Years of Fame. Not only did the Leon poet set forth the main facts about Byron's homosexuality a full century before Byron's more con- 
ventional biographers dared to broach the subject, he also wrote, in a form that is telling and powerful, the earliest published protest against homosexual oppression in England that has survived and the first plea for understanding.

That so much mystery attends the poet's efforts is an indication of the extreme caution reformers in England felt they must use when the laws on homosexuality were at issue. In France the merits of law reform had been discussed openly by Voltaire and others in the eighteenth century. When a new national code was drawn up in Germany during its unification in the $1860 \mathrm{~s}$, the arguments for decriminalization of sodomy were openly debated. But none of Bentham's voluminous writings saw the light of day in nineteenth-century England, nor do we have evidence that they were known to others. A public stance in favor of even so moderate a step as the dropping of the death penalty was regarded as too radical to risk. Homophobia, with the English, was in that age so pronounced a national trait that publication and debate were precluded. To uncover the roots of this striking phenomenon is a challenge to social historians.

\section{NOTES}

'Doris Langley Moore gives a full account of this episode in The Late Lord Byron (Philadelphia: J. B. Lippincott Company, 1961), pp. 12-45.

${ }^{2}$ See G. Wilson Knight, "Who Wrote 'Don Leon'?" Twentieth Century, 156 (1954), 69-79; Chapter v of his Lord Byron's Marriage (New York: MacMillan, 1957); and Doris Langley Moore, Lord Byron: Accounts Rendered (London: John Murray, 1974) pp. 445, 449-53. An edition of Don Leon published in 1934 by the Fortune Press was suppressed; a facsimile of this edition appears in A Homosexual Emancipation Miscellany c. 1835 - 1952 (New York: Arno Press, 1975). References in the present article are to the earliest known edition, Don Leon: A Poem by the late Lord Byron (London: For the Booksellers, 1866).

${ }^{3}$ Notes and Queries, 7 (1853), 66.

${ }^{4}$ The notes that cite A Free Examination are 8, 24, 30, 42, 53, and 68; the arrests are listed in note 56; the other press citations for 1833 are in notes 1 and 88 .

${ }^{5}$ Other notes with material dated later than 1833 mention an arrest in 1841 (88); cite newspapers for 1844 (3), 1849 (first note numbered 51), $1850(7,26), 1853$ (88, 92), and 1856 (second note numbered 51); and refer to the 1853-56 edition of Moore's Memoirs $(5,6,15,30,34)$ and to an Athenaeum article of 1859 (92). Note 88 appears to speak of William Bankes as still alive; he died in 1855 .

${ }^{6}$ See Leon Radzinowicz, The Movement for Reform, Vol. I of A History of English Criminal Law and Its Administration from 1750 (London: Stevens, 1948), pp. 286-97.

${ }^{7}$ Radzinowicz, p. 313.

${ }^{8} 1$ March 1819; Great Britain, Parliament, Parliamentary Debates (London: Hansard, 1819), XXXIX, col. 747

${ }^{9} 2$ March 1819; Parliamentary Debates, XXXIX, col. 790. When he edited his speech for publication, Mackintosh changed his deliberately vague phrase to the more explicit "certain serious sexual offenses." "Speech on Moving for a Committee to Inquire into the State of Criminal Law," Miscellaneous Works (New York: D. Appleton and Company, III, 1873), 529-30.

${ }^{11}$ See Tables Showing the Number of Criminal Offenders Committed for Trial or Bailed . . . in the Year 1836, cited in Louis Crompton, "Gay Genocide: From Leviticus to Hitler," The Gay Academic, ed. Louie Crew (Palm Springs, Calif.: ETC Publications, 197[7]), p. 91. For statistics 
on naval hangings, see Arthur N. Gilbert, "Buggery and the British Navy," Journal of Social History, 10 (1976), 72-98.

15 May 1828, Parliamentary Debates, NS XIX, col. 354.

${ }^{12}$ Times, 5 Aug., p. 4, col. 2; 13 Aug., p. 4, col. 2.

${ }^{13}$ Bentham's notes of 1774 are as yet unpublished; they are contained in boxes 73 and $74 \mathrm{a}$ of the Bentham manuscript collection in the department of Rare Books and Manuscripts of the D. M. S. Watson Library at University College, London. His essay of 1785 has been transcribed and published by the present author in the Journal of Homosexuality, 3 (1978), 389-405, and 4 (1979), 91107. Excerpts from the 1814-16 manuscripts are included in an appendix, "Bentham on Sex," to C. K. Ogden's edition of The Theory of Legislation (New York: Harcourt Brace, 1931), pp. 47397. I plan to give a detailed account of these writings (which run to over five hundred pages) in a monograph on Byron and homosexuality, of which this article forms a part.

${ }^{14}$ Pisanus Fraxi [pseud. of Henry Ashbee], Index Librorum Prohibitorum, Vol. I of Bibliography of Prohibited Books (1877; rpt. New York: Jack Brussel, 1962), p. xxxiv, n. 46.

${ }^{15}$ Fraxi, p. 339.

${ }_{16 " C o l m a n}$ and 'Don Leon'," Twentieth Century, 159 (1956), 562-73.

${ }^{17}$ Lord Byron: Accounts Rendered, pp. 449-55. For the suspected author, see Moore's The Late Lord Byron, pp. 211-13. Moore implies the author was a Mr. Paternoster, of Madras, who contributed to a Byron monument fund in 1826 and then quarreled with the committee.

${ }^{18}$ See his letter to Charles Skinner Matthews, written before embarking at Falmouth, 22 June 1809 , in which Byron speaks of the "hyacinths" he expects to find and enjoy in Asia; Byron's Letters and Journals, ed. Leslie Marchand (Cambridge: Belknap Press, 1973), I, 207.

${ }^{19}$ Note 31 explains that the poet is wrong on this point. Byron did not live in the Lantern, although he occasionally wrote poetry there.

${ }^{20}$ See Byron's letter to Hobhouse from Patras, 4 Oct. 1810; Byron's Letters and Journals, II, 23.

${ }^{21}$ Marchand, Byron: A Biography (New York: Alfred A. Knopf, 1957), I, 90n; Moore, "Byron's Sexual Ambivalence," Lord Byron: Accounts Rendered, pp. 437-59.

${ }^{22 *}$ "People talk of the tendency of my writings, and yet read the Sonnets to Master Hughes."

His Very Voice and Self: Collected Conversations of Lord Byron, ed. E. J. Lovell, Jr. (New York: Macmillan, 1954), p. 552.

${ }^{23} 24$ March 1816; Bentham manuscripts, box 74a, folio 168.

${ }^{244 " G e n e r a l ~ I d e a ~ o f ~ a ~ W o r k, " ~ 1817 ; ~ b o x ~ 161 a, ~ f . ~} 16$.

${ }^{25 *}$ To Dives," Works of Lord Byron, ed. E. H. Coleridge (London: John Murray, 1898), VII, 7.

${ }^{26} 12$ Sept., Byron's Letters and Journals, VIII, 207.

${ }^{27}$ Dictionary of National Biography.

${ }^{28} 10$ July 1826, The Journal of Sir Walter Scott, ed. W. E. K. Anderson (Oxford: Clarendon Press, 1972), p. 170. Anderson identifies the undersecretary as John Cam Hobhouse, but it was in fact Henry Hobhouse, his cousin.

${ }^{29}$ Journal of Sir Walter Scott, p. 162.

${ }^{30}$ Journal of Sir Walter Scott, p. 162.

${ }^{31}$ Annual Register. . . of the Year 1833 (London: Baldwin and Cradock, 1834), p. 246*.

${ }^{32}$ Annual Register... 1833, p. 3.

${ }^{33}$ Annual Register. . . 1833, pp. 314-19*. Wall's case is mentioned as number 5 in note 56.

${ }^{34}$ Letter to John Murray, 19 Nov. 1820; Byron's Letters and Journals, VII, 230

${ }^{35}$ Byron's Letters and Journals, I, 110-12.

${ }^{36}$ Letter to Bankes, 20 Nov. 1819; Byron's Letters and Journals, VI, 243.

${ }^{37} 31$ Aug. and 7 Oct. 1820; Byron's Letters and Journals, VII, 168, 195.

${ }^{38}$ A. L. Rowse, Homosexuals in History (London: Weidenfeld and Nicolson, 1977), pp. 120-25.

${ }^{39} 8$ June, p. 6, col. 5.

${ }^{40}$ Annual Register. . . 1883, p. $169^{*}$.

${ }^{41}$ Great Britain, Parliament, Second Report from His Majesty's Commissioners on Criminal Law, 20 June, 1836, pp. 33, 112.

${ }^{42}$ Parliamentary Debates, 3rd ser., LVIII, cols. 1557, 1568. 